\title{
Economic Analysis of Protected Cultivation: Comparison of Vegetable vs. Fruit
}

\author{
A. A. A. Mohamed ${ }^{1} \&$ M. G. El-Nagger ${ }^{2}$ \\ ${ }^{1}$ Central Laboratory for Agricultural Climate, Agricultural Research Center, Egypt \\ ${ }^{2}$ Agricultural Economics Research Institute, Agricultural Research Center, Egypt \\ Correspondence: A. A. A. Mohamed, Central Laboratory for Agricultural Climate, Agricultural Research Center, \\ 6 Michiel Bakhoom St., P.O. Box 296 Imbaba, Giza 12411, Egypt. Tel: 20-111-884-9915. E-mail: \\ assem20000@yahoo.com
}

Received: December 17, 2017

Accepted: January 20, 2018

Online Published: February 15, 2018

doi:10.5539/jas.v10n3p187

URL: https://doi.org/10.5539/jas.v10n3p187

\begin{abstract}
This research examines solution to overcome the problems of opposition to growing vegetables under protected cultivation, This particular example was chosen to illustrate several important aspects of greenhouse production and marketing that affect profitability such as high prices of vegetable seeds, high prices of materials used in the sterilisation (methyl bromide gas), high prices of plastics in addition to low quality and short duration of use, etc.

The study depended on Bossali protected agriculture unit as example of application to measure the performance and efficiency of production and revenue during the period 1994-2006. Using the traditional system of protected cultivation, compared with a new system of performance and management of production processes, depends on the cultivation of some fruit crops under protected cultivation during the period 2007-2015.

The study analysed the structure cost of production per greenhouse also discussed some economic indicators such as: farm gate prices, total revenue, total costs and net return of cucumber and sweet pepper (as example for vegetables) and navel orange and keitt mango (as example for fruits). This enterprise budget illustration indicates a lack of profitability of this greenhouse vegetable enterprise using these particular assumptions regarding cost, price, and total revenue. Results revealed that net return reached 1234, 3466 Egyptian pound (LE)/greenhouse $\left(540 \mathrm{~m}^{2}\right)$ in navel orange and keitt mango respectively during the study period.
\end{abstract}

Keywords: cost of production, economic analysis, economic indicators, farm gate prices, keitt mango, navel orange, net return, screen net, total revenue

\section{Introduction}

The total world greenhouse vegetable area is 473,466 hectares (Hickman, 2016). The Egyptian protected cultivation area is over twenty thousand hectares; about 4,032 hectares cultivated under glass greenhouses; about 14.053 hectares cultivated under low plastic tunnels and about 2,037 hectares planted under polyethylene greenhouses. Cucumbers and peppers representing $91 \%$ of the cultivated area under protected cultivation, and most of the production of these crops are marketed locally (MALR, 2013).

All agricultural production systems have costs, which affect financial returns and the owner's decision to proceed or forego investments. Monitoring production costs and market prices are critical for greenhouse vegetable crops. In this regard, greenhouse vegetable growers should take into consideration the intricacies of the market in terms of prices at different times of the year as well as the best time to enter the market as these can impact directly on returns to labour, investment and overall profitability (CARDI, 2013). Growers who cannot afford the high initial construction costs of net or plastic houses can grow vegetables under temporary net tunnels. The net tunnels are constructed over each bed, using U-shaped iron or aluminum bars, which are covered with nylon netting (Talekar et al., 2003).

The net return of vegetable crops under greenhouse cultivation was decreasing during the past few years; it is caused by some serious constraints - at the top of these challenges is the leap of the production input prices. In addition to the controversy over the low quality of farming products protected as a result of excessive use of fertilisers and pesticides, which resulted in some farmers stopping to continue farming in protected agriculture (Medany et al., 2007). 
Over the last decade, the Ragusa Province registered a decrease in both terms of greenhouse tomato area and harvested production due to several structural and commercial problems of greenhouse cherry tomato farms that negatively affect their export potential and competitiveness. Consequently, tomato commercialisation is practically limited to local and regional markets, as occurs in other production areas. The results of economic analysis showed that if sales prices of cherry tomato remain at current levels, revenues can barely cover production costs; which equates to a modest income for farmers (Testa et al., 2014).

According to (Mohamed \& Medany, 2015) the findings give evidence to the fact that fruit crops inside net greenhouse produces externalities that create higher benefits for residents. This seems to be a positive result encouraging investments in fruit crops inside net greenhouse management operation, and production of fruits under greenhouses should be applied at new reclaimed lands.

The purpose of the study is to assess the profitability of some vegetables and fruits production under greenhouse system through a cost of production (COP) analysis of primary production.

\section{Method}

Bossali unit of protected cultivation at the north west of Nile Delta, Beheira Governorate, Egypt was used for the applied example to measure the efficiency of production, performance and revenue of cucumber and sweet pepper (as example for vegetables) during the period from 1994-2006 using the traditional system of protected cultivation compared to a new style of performance and management of production processes, and which depends on the cultivation of navel orange and keitt mango (as example for fruits) under protected cropping system during the period 2007-2015. The location of the experimental site was at $31^{\circ} 40^{\prime} \mathrm{N} ; 30^{\circ} 40^{\prime} \mathrm{E}$ longitudes with an elevation of three meters from the sea level.

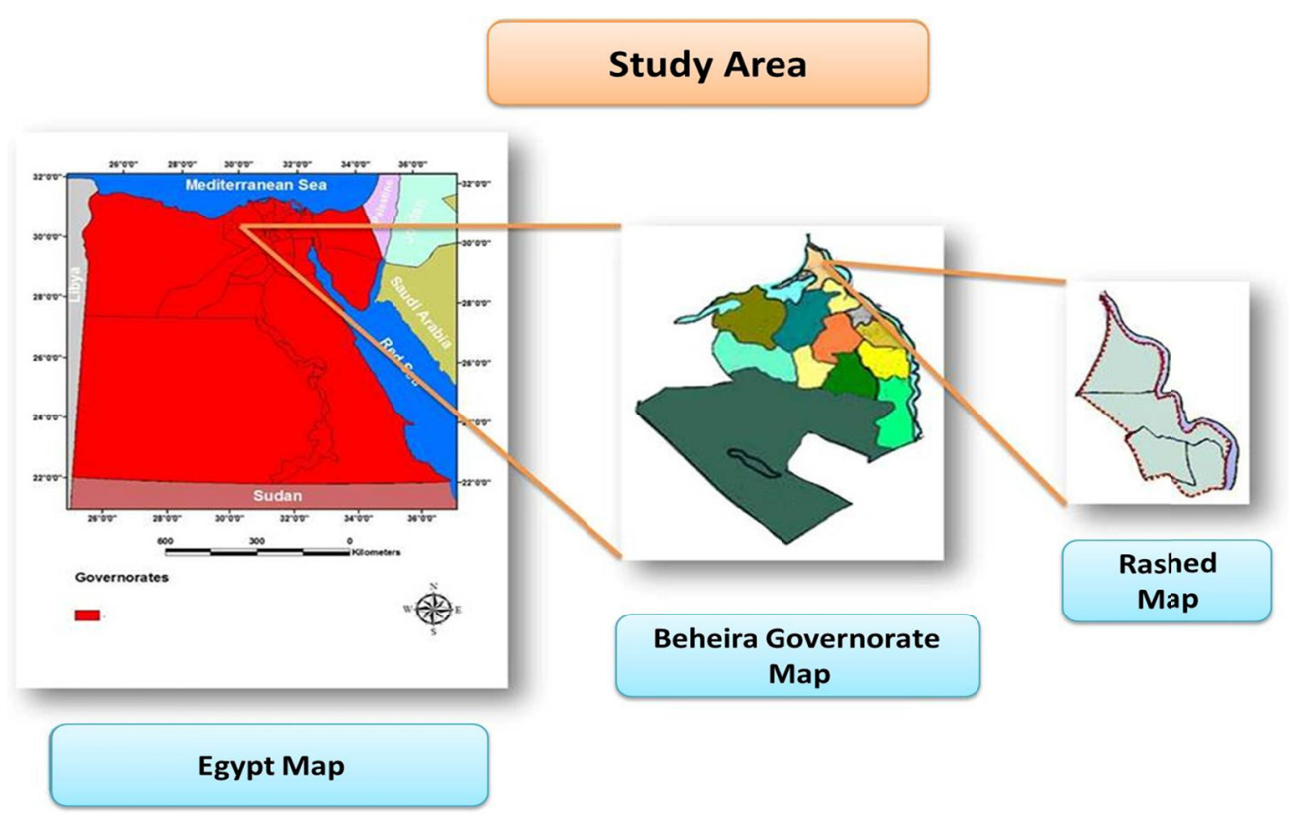

Figure 1. Location of the study area in Egypt

The data collected was statistically analysed and converted to an economic profile of a typical greenhouse module. A $(9 \mathrm{~m} \times 60 \mathrm{~m})$ greenhouse structure of 540 square meters was selected as representing the most common economic module. The main indicators characterising economic efficiency have been determined according to the known formulas: profit, cost per greenhouse, income per greenhouse, and profit per greenhouse. All financial indicators are expressed in Egyptian pound (LE) (1 USD = 9 Egyptian Pound).

This study has employed a budgetary analysis based on actual farm data to evaluate the economic feasibility of sequential crop production systems in a single greenhouse.

The study relied on the use of descriptive analysis to characterise the problem in addition to the quantitative analysis method using some of the various measurements such as simple linear regression. Published and unpublished data were collected to achieve the study's objective. 


\section{Results and Discussion}

\subsection{Vegetable Crops}

\subsubsection{Greenhouse Production Costs for Cucumber}

Productivity efficiency needs use of economic resources in a manner that maximises the production with the least possible cost.

Table 1 focuses on the average cost of production per greenhouse of cucumber in current prices, and relative importance of each item during the period 2002-2006.

The value of plastic was the main cost item (18.25\%) of the average production costs which reached about LE 5039.9 during the study period, followed by seedlings $(15.48 \%)$, soil sterilisation using methyl bromide gas $(14.88 \%)$, value of fertilisers $(11.94 \%)$ and temporary labour wages $(9.42 \%)$.

Table 1. Production costs of a cucumber greenhouse $\left(540 \mathrm{~m}^{2}\right)$ and relative importance of each item during the period 2002-2006

\begin{tabular}{llllllll}
\hline Cost items & 2002 & 2003 & 2004 & 2005 & 2006 & Aver. & $\%$ \\
\hline Land preparation (LE) & 28 & 29 & 30 & 33 & 35 & 32.67 & 0.65 \\
Transplants (LE) & 540 & 600 & 660 & 780 & 900 & 780 & 15.48 \\
Irrigation (LE) & 160 & 170 & 180 & 190 & 200 & 190 & 3.77 \\
Fertilisation (LE) & 437 & 487 & 541 & 611 & 653 & 601.7 & 11.94 \\
Insecticides (LE) & 368 & 391 & 414 & 437 & 460 & 437 & 8.67 \\
Sterilisation (LE) & 450 & 525 & 675 & 750 & 825 & 750 & 14.88 \\
Hiring labour wages (LE) & 425 & 450 & 450 & 475 & 500 & 475 & 9.42 \\
Threads and pillars (LE) & 124 & 132 & 132 & 140 & 150 & 140.7 & 2.79 \\
Transportation (LE) & 150 & 140 & 130 & 160 & 200 & 163.3 & 3.24 \\
Plastic (LE) & 600 & 660 & 840 & 960 & 960 & 920 & 18.25 \\
Maintenance (LE) & 75 & 80 & 85 & 90 & 100 & 91.7 & 1.82 \\
Management (LE) & 128 & 142 & 166 & 186 & 200 & 184 & 3.65 \\
Deduction (LE) & 273 & 253 & 195 & 292 & 335 & 273.9 & 5.43 \\
Total costs (LE) & 3758 & 4059 & 4498 & 5104 & 5518 & 5039.9 & 100 \\
\hline
\end{tabular}

Source: Calculated using the data taken from MALR, ARC, CLAC, Bossali unit, unpublished data.

\subsubsection{Greenhouse Production Costs for Sweet Pepper}

Table 2 explains the average cost of production per greenhouse of sweet pepper in current prices and relative importance of each item during the period 2002-2006.

The value of plastic was the main cost item (22.68\%) of the average production costs which reached about LE 6761.8 during the study period, followed by soil sterilisation using methyl bromide gas (17.55\%), temporary labour wages (14.05\%), value of fertilisers (13.0\%) and seedlings (9.76\%).

\subsubsection{Economic Indicators of the Cucumber Production under Greenhouse}

\section{(1) The Evolution of Farm Gate Prices/kg for Cucumber}

Table 3 illustrates the economic indicators and statistical analysis for the production of cucumber greenhouse during the period 1994-2006. The farm gate prices during the study period reached a minimum LE 0.57 in 2001, while the maximum was LE 1.03 in 1997. The Equation 1 in Table 4 showed that the farm gate prices of cucumber had increased at annual statistical non-significant rate during the period 1994-2006.

\section{(2) The Evolution of Total Revenue/Greenhouse for Cucumber}

Total revenue per greenhouse is the outcome of productivity per greenhouse and farm gate prices, Table 3 details the total revenue during the period 1994-2006 reached a minimum LE 2437 in 1999, while the maximum was LE 4792 in 2006 - this can be attributed to the increase in prices and total production. The Equation 2 in Table 4 showed that the total revenue of cucumber had increased at annual statistical non-significant rate during the study period. 
Table 2. Production costs of sweet pepper greenhouse $\left(540 \mathrm{~m}^{2}\right)$ and relative importance of each item during the period 2002-2006

\begin{tabular}{llllllll}
\hline Cost items & 2002 & 2003 & 2004 & 2005 & 2006 & Aver. & $\%$ \\
\hline Land preparation (LE) & 28 & 29 & 30 & 33 & 35 & 32.67 & 0.48 \\
Transplants (LE) & 480 & 540 & 600 & 660 & 720 & 660.00 & 9.76 \\
Irrigation (LE) & 165 & 170 & 175 & 185 & 190 & 183.33 & 2.71 \\
Fertilisation (LE) & 639 & 713 & 791 & 892 & 954 & 879.00 & 13.00 \\
Insecticides (LE) & 380 & 391 & 403 & 426 & 437 & 422.00 & 6.24 \\
Sterilisation (LE) & 720 & 840 & 1080 & 1200 & 1320 & 1200.00 & 17.75 \\
Hiring labor wages (LE) & 850 & 900 & 900 & 950 & 1000 & 950.00 & 14.05 \\
Threads and pillars (LE) & 140 & 150 & 155 & 160 & 170 & 161.67 & 2.39 \\
Transportation (LE) & 225 & 150 & 140 & 150 & 150 & 146.67 & 2.17 \\
Plastic (LE) & 1000 & 1100 & 1400 & 1600 & 1600 & 1533.33 & 22.68 \\
Maintenance (LE) & 75 & 80 & 85 & 90 & 100 & 91.67 & 1.36 \\
Management (LE) & 169 & 188 & 222 & 248 & 261 & 243.87 & 3.61 \\
Deduction (LE) & 342 & 224 & 191 & 244 & 338 & 257.60 & 3.81 \\
Total costs (LE) & 5213 & 5475 & 6173 & 6838 & 7275 & 6761.80 & 100 \\
\hline
\end{tabular}

Source: Calculated using the data taken from MALR, ARC, CLAC, Bossali unit, unpublished data.

Table 3. Evolution of cucumber farm gate prices, total revenue, total costs, and net return under greenhouse (540 $\mathrm{m}^{2}$ ) during the period 1994-2006

\begin{tabular}{lllll}
\hline Years & $\begin{array}{l}\text { Farm gate prices } \\
(\mathrm{LE} / \mathrm{kg})\end{array}$ & $\begin{array}{l}\text { Total revenue } \\
(\mathrm{LE} / \text { greenhouse) }\end{array}$ & $\begin{array}{l}\text { Total cost } \\
\text { (LE/greenhouse) }\end{array}$ & $\begin{array}{l}\text { Net return } \\
\text { (LE/greenhouse) }\end{array}$ \\
\hline 1994 & 0.99 & 3573 & 2070 & 1503 \\
1995 & 0.94 & 4107 & 2201 & 1905 \\
1996 & 0.89 & 3813 & 2275 & 1538 \\
1997 & 1.03 & 3247 & 2670 & 576 \\
1998 & 0.8 & 3142 & 2649 & 493 \\
1999 & 0.65 & 2437 & 2772 & -334 \\
2000 & 0.64 & 3244 & 3145 & 98 \\
2001 & 0.57 & 2813 & 3358 & -545 \\
2002 & 0.77 & 3896 & 3758 & 139 \\
2003 & 0.75 & 3617 & 4059 & -443 \\
2004 & 0.8 & 2780 & 4498 & -1718 \\
2005 & 0.97 & 4167 & 5104 & -937 \\
2006 & 0.96 & 4792 & 5518 & -726 \\
\hline
\end{tabular}

Source: Calculated using the data taken from MALR, ARC, CLAC, Bossali unit, unpublished data.

(3) The Evolution of Total Cost/Greenhouse for Cucumber

Total cost of cucumber production during the period 1994-2006 increased from a minimum LE 2070 in 1994 to the maximum LE 5518 in 2006 - more than double from the year 1994 (Table 3). The Equation 3 in Table 4 showed that the total cost of cucumber production had increased at annual statistical significant rate which reached LE 280.5 during the study period, and the coefficient of determination reached 0.94; which means that $94 \%$ of the changes in the production costs attributed to the factors that reflect the impact of variable time.

(4) The Evolution of Net Return/Greenhouse for Cucumber

Net return depends on the amount of the increase in total revenue compared to the increase in production cost. Cucumber's net return was high during the first years of the study period, followed by a decrease until the end of this period due to falling in farm gate prices and increasing in the production costs (Table 3); it reached the minimum LE (-1718) in 2004 and the maximum was LE 1905 in 1995 (Table 3). As shown in Equation 4 in Table 4, net return of cucumber had decreased at annual statistical significant rate of approximately LE 245 during the study period, and the coefficient of determination reached 0.80 ; which means that $80 \%$ of the changes 
in the net return attributed to the factors which reflect the impact of variable.

Table 4. General trend equations of the evolution of cucumber farm gate prices, total revenue, total costs, and net return

\begin{tabular}{llllll}
\hline Items & Equation & $\mathrm{R}^{2}$ & $\mathrm{~F}$ & $\mathrm{~T}$-values & No \\
\hline Farm gate prices (LE/kg) & $\hat{\mathrm{Y}} \mathrm{i}=0.81+0.008 \mathrm{Xi}$ & 0.04 & 0.45 & 0.67 & 1 \\
Total revenue (LE/greenhouse) & $\hat{\mathrm{Y}} \mathrm{i}=3260.9+35.56 \mathrm{Xi}$ & 0.04 & 0.52 & 0.7 & 2 \\
Total cost (LE/greenhouse) & $\hat{\mathrm{Y}} \mathrm{i}=1426.6+280.5 \mathrm{Xi}$ & 0.94 & 183.4 & 13.5 & 3 \\
Net return (LE/greenhouse) & $\hat{\mathrm{Y}} \mathrm{i}=1834.34-245 \mathrm{Xi}$ & 0.80 & 44.29 & -6.66 & 4 \\
\hline
\end{tabular}

Note. $\hat{\mathrm{Y}}_{\mathrm{i}}=$ the estimated value for the dependent variable in the year $\mathrm{i}, \mathrm{X}_{\mathrm{i}}=$ Reflect time variable in the year $\mathrm{i}, \mathrm{i}=$ $1,2,3, \ldots 13 ; \mathrm{R}^{2}=$ Coefficient of determination; $\mathrm{F}=\mathrm{F}$-Test, a statistical test in which the test statistic is based on the F-distribution under the null hypothesis; $\mathrm{T}=\mathrm{T}$-Test, test on individual regression coefficients.

Source: Calculated using the data taken from Table 3.

\subsubsection{Economic Indicators of the Sweet Pepper Production under Greenhouse}

\section{(1) The Evolution of Farm Gate Prices/kg for Sweet Pepper}

Table 5 illustrates the economic indicators and statistical analysis for the production of sweet pepper greenhouse during the period 1994-2006. The farm gate prices during the study period reached LE 0.93 in the basic year, while reached LE 1.61 in 2006. The Equation 1 in Table 6 showed that the farm gate prices of sweet pepper had increased at annual statistical non-significant rate during the period 1994-2006.

(2) The Evolution of Total Revenue/Greenhouse for Sweet Pepper

Table 5 details the total revenue during the period 1994-2006 reached a minimum LE 2730 in 2004, while the maximum was LE 5952 in 1994 (basic year). As shown in Equation 2 in Table 6, the total revenue of sweet pepper had increased at annual statistical significant rate during the study period.

(3) The Evolution of Total Cost/Greenhouse for Sweet Pepper

Table 5 shows the total cost during the period 1994-2006 increased from a minimum of approximately LE 3002 in 1994, and then increased to reach the maximum around LE 7275 in 2006-almost doubled compared to the year 1994. The Equation 3 in Table 6 showed that total cost of sweet pepper had increased at annual statistical significant rate that reached LE 365.48 during the study period, and the coefficient of determination reached 0.96; which means that $96 \%$ of the changes in the total cost attributed to the factors that reflect the impact of variable time.

Table 5. Evolution of sweet pepper farm gate prices, total revenue, total costs, and net return under greenhouse $\left(540 \mathrm{~m}^{2}\right)$ during the period 1994-2006

\begin{tabular}{lllll}
\hline years & $\begin{array}{l}\text { Farm gate prices } \\
(\mathrm{LE} / \mathrm{kg})\end{array}$ & $\begin{array}{l}\text { Total revenue } \\
\text { (LE/greenhouse) }\end{array}$ & $\begin{array}{l}\text { Total cost } \\
\text { (LE/greenhouse) }\end{array}$ & $\begin{array}{l}\text { Net return } \\
\text { (LE/greenhouse) }\end{array}$ \\
\hline 1994 & 0.93 & 5952 & 3002 & 2950 \\
1995 & 0.99 & 5247 & 3067 & 2180 \\
1996 & 0.94 & 4136 & 3078 & 1058 \\
1997 & 1.15 & 3795 & 3391 & 404 \\
1998 & 0.99 & 5247 & 3760 & 1487 \\
1999 & 0.67 & 4556 & 4074 & 482 \\
2000 & 0.68 & 4352 & 4411 & -59 \\
2001 & 0.91 & 3458 & 4624 & -1166 \\
2002 & 0.94 & 4888 & 5213 & -325 \\
2003 & 1.00 & 3200 & 5475 & -2275 \\
2004 & 1.05 & 2730 & 6173 & -3443 \\
2005 & 1.16 & 3480 & 6838 & -3358 \\
2006 & 1.61 & 4830 & 7275 & -2445 \\
\hline
\end{tabular}

Source: Calculated using the data taken from MALR, ARC, CLAC, Bossali unit, unpublished data. 
Table 6. General trend equations of the evolution of sweet pepper farm gate prices, total revenue, total costs, and net return

\begin{tabular}{llllll}
\hline Items & Equation & $\mathrm{R}^{2}$ & $\mathrm{~F}$ & T-values & No \\
\hline Farm gate prices (LE/kg) & $\hat{\mathrm{Y}} \mathrm{i}=0.81+0.03 \mathrm{Xi}$ & 0.21 & 3 & 1.7 & 1 \\
Total revenue (LE/greenhouse) & $\hat{\mathrm{Y}} \mathrm{i}=5251.3-136.2 \mathrm{Xi}$ & 0.32 & 5.17 & -2.27 & 2 \\
Total cost (LE/greenhouse) & $\hat{\mathrm{Y}} \mathrm{i}=2083.6+365.84 \mathrm{Xi}$ & 0.96 & 244.3 & 15.6 & 3 \\
Net return (LE/greenhouse) & $\hat{\mathrm{Y}} \mathrm{i}=3167.7-502.06 \mathrm{Xi}$ & 0.89 & 91.9 & -9.58 & 4 \\
\hline
\end{tabular}

Note. $\hat{\mathrm{Y}}_{\mathrm{i}}=$ the estimated value for the dependent variable in the year $\mathrm{i}, \mathrm{X}_{\mathrm{i}}=$ Reflect time variable in the year $\mathrm{i}, \mathrm{i}=$ $1,2,3, \ldots 13 ; \mathrm{R}^{2}=$ Coefficient of determination; $\mathrm{F}=\mathrm{F}$-Test, a statistical test in which the test statistic is based on the F-distribution under the null hypothesis; $\mathrm{T}=\mathrm{T}$-Test, test on individual regression coefficients.

Source: Calculated using the data taken from Table 5.

\section{(4) The Evolution of Net Return/Greenhouse for Sweet Pepper}

Table 5 explains an increase net return of sweet pepper during the first years of the study period, followed by a decrease until the end of this period due to falling in farm gate prices and increasing in the production costs (Table 5); it reached the minimum LE (-3443) in 2004 and the maximum was LE 2950 in 1994 (Table 5). As shown in Equation 4 in Table 6, net return of sweet pepper had decreased at annual statistical significant rate of approximately LE 502.06 and the coefficient of determination reached 0.89 ; which means that $89 \%$ of the changes in the net return attributed to the factors reflecting the impact of variable.

\subsection{Fruit Crops}

\subsubsection{Production Costs of Navel Orange under Screen Net Greenhouse}

Table 7 details the average cost of production per greenhouse of navel orange in current prices, and relative importance of each item during the period 2011-2015.

The highest production costs were the value of fertilisation at $(26.77 \%)$ of the average production costs which reached about LE 1404 during the study period. This was followed by value of screen net $(22.43 \%)$, management wages (21.08\%), value of irrigation (5.91\%) and insecticides (4.2\%).

\subsubsection{Production Costs of Keitt Mango under Screen Net Greenhouse}

Table 8 presented the average cost of production per greenhouse of keitt mango in current prices, and relative importance of each item during the period 2011-2015.

The highest production costs were the value of fertilisation at $(25.1 \%)$ of the average production costs which reached about LE 1686 during the study period. This was followed by value of screen net (18.7\%), management wages $(17.6 \%)$, value of insecticides (16.6\%) and irrigation $(5 \%)$.

Table 7. Production costs of navel orange greenhouse $\left(540 \mathrm{~m}^{2}\right)$ and relative importance of each item during the period 2011-2015

\begin{tabular}{llllllll}
\hline Cost Items & 2011 & 2012 & 2013 & 2014 & 2015 & Aver. & $\%$ \\
\hline Pruning (LE) & 52 & 55 & 55 & 65 & 65 & 58 & 4.16 \\
Hoeing (LE) & 40 & 45 & 55 & 65 & 65 & 54 & 3.85 \\
Fertilisation (LE) & 335 & 350 & 385 & 400 & 410 & 376 & 26.77 \\
Irrigation (LE) & 70 & 80 & 85 & 90 & 90 & 83 & 5.91 \\
Herbicides (LE) & 30 & 35 & 35 & 40 & 45 & 37 & 2.63 \\
Insecticides (LE) & 50 & 55 & 60 & 65 & 65 & 59 & 4.20 \\
Screen net (LE) & 300 & 300 & 325 & 325 & 325 & 315 & 22.43 \\
Fruit branch support (LE) & 25 & 30 & 30 & 35 & 35 & 31 & 2.21 \\
Maintenance (LE) & 40 & 40 & 45 & 50 & 50 & 45 & 3.20 \\
Management (LE) & 250 & 280 & 300 & 320 & 330 & 296 & 21.08 \\
Others (LE) & 50 & 50 & 50 & 50 & 50 & 50 & 3.56 \\
Total costs (LE) & 1242 & 1320 & 1425 & 1505 & 1530 & 1404 & 100 \\
\hline
\end{tabular}

Source: Calculated using the data taken from MALR, ARC, CLAC, Bossali unit, unpublished data. 
Table 8. Production costs of keitt mango greenhouse $\left(540 \mathrm{~m}^{2}\right)$ and relative importance of each item during the period 2011-2015

\begin{tabular}{llllllll}
\hline Cost Items & 2011 & 2012 & 2013 & 2014 & 2015 & Aver. & $\%$ \\
\hline Pruning (LE) & 55 & 60 & 60 & 65 & 65 & 61 & 3.6 \\
Hoeing (LE) & 40 & 45 & 55 & 65 & 70 & 55 & 3.3 \\
Fertilisation (LE) & 350 & 400 & 420 & 450 & 500 & 424 & 25.1 \\
Irrigation (LE) & 70 & 80 & 85 & 95 & 95 & 85 & 5.0 \\
Herbicides (LE) & 40 & 40 & 45 & 45 & 50 & 44 & 2.6 \\
Insecticides (LE) & 270 & 275 & 280 & 285 & 290 & 280 & 16.6 \\
Screen net (LE) & 300 & 300 & 325 & 325 & 325 & 315 & 18.7 \\
Fruit branch support (LE) & 25 & 30 & 30 & 35 & 35 & 31 & 1.8 \\
Maintenance (LE) & 40 & 40 & 45 & 50 & 50 & 45 & 2.7 \\
Management (LE) & 250 & 280 & 300 & 320 & 330 & 296 & 17.6 \\
Others (LE) & 50 & 50 & 50 & 50 & 50 & 50 & 3.0 \\
Total costs (LE) & 1490 & 1600 & 1695 & 1785 & 1860 & 1686 & 100 \\
\hline
\end{tabular}

Source: Calculated using the data taken from MALR, ARC, CLAC, Bossali unit, unpublished data.

\subsubsection{Economic Indicators of the Navel Orange Production under Screen Net Greenhouse}

(1) The Evolution of Farm Gate Prices/kg for Navel Orange

Table 9 shows the farm gate prices during the period 1994-2006. Farm gate prices reached LE 1.10 in 2007 and LE 1.20 in 2015 with an average LE 1.09. The Equation 1 in Table 10 showed that the farm gate prices of navel orange had increased at annual statistical non-significant rate during the study period.

(2) The Evolution of Total Revenue/Greenhouse for Navel Orange

Table 9 illustrates total revenue during the period 2007-2015 reached a minimum around LE 330 in 2007, while the maximum was LE 3780 in 2015. This might be attributed to the increase in total production. The Equation 2 in Table 10 showed that the total revenue of navel orange had increased at annual statistical non-significant rate during the study period.

(3) The Evolution of Total Cost/Greenhouse for Navel Orange

Table 9 explains the total cost during 2007-2015 increased from a minimum of LE 400 in 2008 to the maximum of LE 1530 in 2015-almost tripled compared to the year 2008. As shown in Equation 3 in Table 10, total cost of navel orange had increased at annual statistical significant rate that reached LE 162.5 during the study period and the coefficient of determination reached 0.92 ; which means that $92 \%$ of the changes in the total cost attributed to the factors and that reflects the impact of variable time.

(4) The Evolution of Net Return/Greenhouse for Navel Orange

Table 9 shows an increase in net return of navel orange during the study period reached the minimum around LE $(-120)$ in 2007, and the maximum was LE 2250 in 2015. The Equation 4 in Table 10 showed that the net return of navel orange had increased at annual statistical significant rate that reached LE 229.3 during the study period, and the coefficient of determination reached 0.87 ; which means that $87 \%$ of the changes in the net return attributed to the factors that reflect the impact of variable. 
Table 9. Evolution of navel orange farm gate prices, total revenue, total costs, and net return under greenhouse during the period 2007-2015

\begin{tabular}{lllll}
\hline years & $\begin{array}{l}\text { Farm gate prices } \\
(\mathrm{LE} / \mathrm{kg})\end{array}$ & $\begin{array}{l}\text { Total revenue } \\
(\mathrm{LE} / \text { greenhouse) }\end{array}$ & $\begin{array}{l}\text { Total cost } \\
\text { (LE/greenhouse) }\end{array}$ & $\begin{array}{l}\text { Net return } \\
\text { (LE/greenhouse) }\end{array}$ \\
\hline 2007 & 1.10 & 330 & 450 & -120 \\
2008 & 1.20 & 1080 & 400 & 680 \\
2009 & 1.10 & 1650 & 650 & 1000 \\
2010 & 1.05 & 2048 & 750 & 1298 \\
2011 & 1.10 & 2640 & 1242 & 1398 \\
2012 & 1.00 & 2700 & 1320 & 1380 \\
2013 & 1.00 & 2850 & 1425 & 1425 \\
2014 & 1.10 & 3300 & 1505 & 1795 \\
2015 & 1.20 & 3780 & 1530 & 2250 \\
Average & 1.09 & 2264.22 & 1030.22 & 1234.00 \\
\hline
\end{tabular}

Source: Calculated using the data taken from MALR, ARC, CLAC, Bossali unit, unpublished data.

\subsubsection{Economic Indicators of the Keitt Mango Production under Screen Net Greenhouse}

(1) The Evolution of Farm Gate Prices/kg for Keitt Mango

Table 11 shows the farm gate prices during the study period reached LE 10 in 2007; thus decreased to reach LE 9 in 2015. The Equation 1 in Table 12 showed that the farm gate prices of keitt mango had decreased at annual statistical significant rate that reached LE 0.17 during the period 2007-2015.

(2) The Evolution of Total Revenue/Greenhouse for Keitt Mango

Table 11 focuses on the total revenue during the period 2007-2015 reached a minimum around LE 500 in 2007 while the maximum was LE 7920 in 2014. The Equation 2 in Table 12 showed that the total revenue of keitt mango had increased at annual statistical significant rate that reached LE 991.16, while the coefficient of determination reached 0.90 ; which means that $90 \%$ of the changes in the total revenue attributed to the factors that reflect the impact of variable.

Table 10. General trend equations of the evolution of navel orange farm gate prices, total revenue, total costs, and net return during the period 2007-2015

\begin{tabular}{llllll}
\hline Items & Equation & $\mathrm{R}^{2}$ & $\mathrm{~F}$ & $\mathrm{~T}$ & No \\
\hline Farm gate prices (LE/kg) & $\hat{\mathrm{Y}} \mathrm{i}=1.1-0.0025 \mathrm{Xi}$ & 0.008 & 0.06 & -0.25 & 1 \\
Total revenue (LE/greenhouse) & $\hat{\mathrm{Y}} \mathrm{i}=304.8+391.8 \mathrm{Xi}$ & 0.96 & 161.7 & 12.7 & 2 \\
Total cost (LE/greenhouse) & $\hat{\mathrm{Y}} \mathrm{i}=217.3+162.5 \mathrm{Xi}$ & 0.92 & 84.9 & 9.2 & 3 \\
Net return (LE/greenhouse) & $\hat{\mathrm{Y}} \mathrm{i}=87.5+229.3 \mathrm{Xi}$ & 0.87 & 46.3 & 6.8 & 4 \\
\hline
\end{tabular}

Note. $\hat{Y}_{\mathrm{i}}=$ the estimated value for the dependent variable in the year $\mathrm{i}, \mathrm{X}_{\mathrm{i}}=$ Reflect time variable in the year $\mathrm{i}, \mathrm{i}=$ $1,2,3, \ldots 13 ; \mathrm{R}^{2}=$ Coefficient of determination; $\mathrm{F}=\mathrm{F}$-Test, a statistical test in which the test statistic is based on the F-distribution under the null hypothesis; $\mathrm{T}=\mathrm{T}$-Test, test on individual regression coefficients.

Source: Calculated using the data taken from Table 9. 
Table 11. Evolution of keitt mango farm gate prices, total revenue, total costs, and net return under greenhouses during the period 2007-2015

\begin{tabular}{lllll}
\hline years & $\begin{array}{l}\text { Farm gate prices } \\
(\mathrm{LE} / \mathrm{kg})\end{array}$ & $\begin{array}{l}\text { Total revenue } \\
\text { (LE/greenhouse) }\end{array}$ & $\begin{array}{l}\text { Total cost } \\
\text { (LE/greenhouse) }\end{array}$ & $\begin{array}{l}\text { Net return } \\
\text { (LE/greenhouse) }\end{array}$ \\
\hline 2007 & 10.00 & 500 & 950 & -450 \\
2008 & 9.50 & 1710 & 1000 & 710 \\
2009 & 9.00 & 2430 & 1200 & 1230 \\
2010 & 9.00 & 3645 & 1380 & 2265 \\
2011 & 8.50 & 6120 & 1490 & 4630 \\
2012 & 8.50 & 6885 & 1600 & 5285 \\
2013 & 8.50 & 7650 & 1695 & 5955 \\
2014 & 8.00 & 7920 & 1785 & 6135 \\
2015 & 9.00 & 7290 & 1860 & 5430 \\
Average & 8.89 & 4906 & 1440.00 & 3466 \\
\hline
\end{tabular}

Source: Calculated using the data taken from MALR, ARC, CLAC, Bossali unit, unpublished data.

\section{(3) The Evolution of Total Costs/Greenhouse for Keitt Mango}

Table 11 explains the total cost during 2007-2015 reached a minimum of LE 950 in 2007 and then increased to reach the maximum around LE 1860 in 2015-doubled compared to the year 2007. The Equation 3 in Table 12 showed that the total cost of keitt mango had increased at annual statistical significant rate that reached LE 120.08 during the study period, while the coefficient of determination reached 0.98 ; which means that $98 \%$ of the changes in the total cost attributed to the factors that reflect the impact of variable time.

\section{(4) The Evolution of Net Return/Greenhouse for Keitt Mango}

Table 11 focuses on an increasing net return of keitt mango during 2007-2014 followed by a decrease in the year 2015 due to the decreased in the yield. Net return reached the minimum around LE (-450) in 2007 and the maximum was LE 6135 in 2014. The Equation 4 in Table 12 showed that the net return of keitt mango had increased at annual statistical significant rate reached LE 871.08 and the coefficient of determination reached 0.89 ; which means that $89 \%$ of the changes in the net return attributed to the factors that reflect the impact of variable.

Table 12. General trend equations of the evolution of keitt mango farm gate prices, total revenue, total costs, and net return

\begin{tabular}{llllll}
\hline Items & Equation & $\mathrm{R}^{2}$ & $\mathrm{~F}$ & $\mathrm{~T}$ & No \\
\hline Farm gate prices (LE/kg) & $\hat{\mathrm{Y}} \mathrm{i}=9.72-0.17 \mathrm{Xi}$ & 0.60 & 9.5 & -3.08 & 1 \\
Total revenue (LE/greenhouse) & $\hat{\mathrm{Y}} \mathrm{i}=-50.27+991.16 \mathrm{Xi}$ & 0.90 & 67.7 & 8.23 & 2 \\
Total cost (LE/greenhouse) & $\hat{\mathrm{Y}} \mathrm{i}=839.6+120.08 \mathrm{Xi}$ & 0.98 & 331.8 & 18.2 & 3 \\
Net return (LE/greenhouse) & $\hat{\mathrm{Y}} \mathrm{i}=-889.86+871.08 \mathrm{Xi}$ & 0.89 & 56.05 & 7.48 & 4 \\
\hline
\end{tabular}

Note. $\hat{\mathrm{Y}}_{\mathrm{i}}=$ the estimated value for the dependent variable in the year $\mathrm{i}, \mathrm{X}_{\mathrm{i}}=$ Reflect time variable in the year $\mathrm{i}, \mathrm{i}=$ $1,2,3, \ldots 13 ; \mathrm{R}^{2}=$ Coefficient of determination; $\mathrm{F}=\mathrm{F}$-Test, a statistical test in which the test statistic is based on the F-distribution under the null hypothesis; $\mathrm{T}=\mathrm{T}$-Test, test on individual regression coefficients.

Source: Calculated using the data taken from Table 11.

\section{Conclusions}

The greenhouse vegetable growing systems must be redesigned to increase efficiency, yields and reduce costs. The study concluded that each situation must be evaluated separately; if profits from vegetables greenhouse do not appear feasible, there are alternative crops which may be profitable. e.g., fruit crops (Orange, Mango). All farmers should adopt a technology; they must see an advantage or expect to obtain greater utility in adopting it. In the light of this study, it is argued that without a significant difference in outcomes between two options and in the returns from alternative and conventional practices, it is less likely that farmers, especially small-scale farmers, will adopt the new practice. Since adoption of a practice is guided by the utility expected 
from it, the effort put into adopting it is reflective of this anticipated utility.

\section{Acknowledgements}

Appreciation is expressed to Prof. Abdelmonem A. M. Esmail (CLAC) for providing the necessary data and technical contributions.

\section{References}

CARDI (Caribbean Agricultural Research and Development Institute). (2013). Financial aspects of greenhouse vegetables production systems in Jamaica and Trinidad \& Tobago (Technical Report, 2013).

Hickman, G. W. (2016). International Greenhouse Vegetable Production Statistics.

MALR (Ministry of Agriculture and Land Reclamation), ARC (Agricultural Research Center), \& CLAC (Central Laboratory for Agricultural Climate). (n.d.). Bossali unit (unpublished data). Cairo, Egypt.

MALR (Ministry of Agriculture and Land Reclamation). (2013). Economic Affairs Sector, 2013. Cairo, Egypt.

Medany, M. A., Hassanein, M. K., \& Esmail, A. A. M. (2007). Integrated sustainable management systems for problems of modern agriculture, Egypt. J. Appl., Sci., 22(12).

Mohamed, A. A. A., \& Medany, M. A. (2015). Economic indicators of navel orange and keitt mango: Comparison of net greenhouses vs open field. International Journal of Development Research, 5(6), 4640-4644.

Talekar, N. S., Su, F. C., \& Lin, M. Y. (2003). How to produce safer leafy vegetables in net houses and net tunnels (p. 18). Asian Vegetable Research and Development Center, Shanhua, Tainan, Taiwan.

Testa, R., di Trapani, A. M., Sgroi, F., \& Tudisca, S. (2014). Economic sustainability of Italian greenhouse cherry tomato. Sustainability, 6, 7967-7981. https://doi.org/10.3390/su6117967

\section{Copyrights}

Copyright for this article is retained by the author(s), with first publication rights granted to the journal.

This is an open-access article distributed under the terms and conditions of the Creative Commons Attribution license (http://creativecommons.org/licenses/by/4.0/). 